\title{
RAZLOŽNOST ODGOJA
}

\author{
Milan Polić
}

Već dva i po tisućljeća, od Sokrata i Platona, odgoj je u žiži filozofskog interesa. Svojom osobnošću, koja je djelatno slijedila njegov unutarnji glas, a ne narodnu predaju, Sokrat (470.-399.) se suprotstavio naslijeđenoj i neupitnoj običajnosti. No, da je taj unutarnji glas bio samo glas njegovih trenutnih želja, tj. površna samovolja, a ne glas razuma (Prilog 1) što uvijek iznova nastoji svijet misliti dosljedno, bio bi Sokrat tek jedan od mnogih u to doba koji su svoju samovolju htjeli izdići do samovlađa. Ali Sokrat je prezirao samovlađe, kao što je prezirao i svjetinu. Svojom majeutikom ${ }^{1}$ poticao je i podupirao druge neka razumom potraže istinu u sebi, a ne u poukama što su se tradicijom prenosile bez propitivanja. I ta je istina trebala biti osnovom za život, tj. život se, a ne privid života, mogao zbivati i zbivao se tek tamo i tada gdje se i kada odjelovljavala ${ }^{2}$ razumom dokučena istina. Doduše, Sokrat je svijet i istinu o njemu shvaćao nepovijesno. Svojim dijalozima nije dopirao do svijesti o divergentnom mišljenju i stvaralačkom djelovanju uma (Prilog 2), nego je tek dosljedno utvrđivao moguće stanje razuma, navodeći tendencioznim pitanjima sugovornike na unaprijed pripremljene zaključke. Ali činio je to svakodnevno u još uvijek živom i otvorenom dijalogu s drugima, čime je vlastito poimanje istine kao apsolutne i konačne uvijek iznova stavljao na kušnju. Svojim pak dosljednim životom kojim je svjedočio dosljednost svoga mišljenja, Sokrat je postavljao osnove za poimanje osobnosti raz-umnim samoodređenjem i slobodom.

* Tekst je ponešto izmijenjena i skraćena verzija rada: Milan Polić, »Razložnost odgoja«, Nastavnički suputnik, 2010./11., Znamen, Zagreb 2010., str. 189-212. Zahvaljujemo Borisu Drandiću (Znamen d.o.o.) i Rajki Polić na odobrenjima za objavljivanje.

${ }^{1}$ Majeutika (grč. maieutikē tékhne: primaljska vještina): postupak kojim je Sokrat pomagao sugovorniku da, u prenesenom smislu, »porodi« istinu kojom je »bremenit«. Postupak je započinjao ironijom kojom je Sokrat navodio sugovornika neka posumnja u ispravnost svojih stavova kako bi ga zatim u razgovoru, prikladnim pitanjima, vodio prema spoznaji i iznošenju istine što je (svatko) nosi u sebi.

${ }^{2}$ Odjelovljenje: djelatnost što ostvaruje neku misao; postajanje djelom, pretvaranje (misli) u djelo. 
Pa iako sebe nije smatrao ničijim učiteljem, nego tek majeutičarem (duhovnom primaljom) koji pomaže rođenju istine, Sokrat je bio veliki učitelj i odgajatelj. Bio je to unatoč manipulativnosti njegove majeutike, jer je ljude poticao neka traže, upoznaju sami sebe i žive u skladu sa svojom istinom. Njegovo pogrešno uvjerenje kako je istina jedna $\mathrm{i}$ ista za sve ljude, ograničavalo je kako doseg njegove majeutike tako i doseg njegove osobne slobode, ali bio je to ipak veliki iskorak prema osobnosti što je ostavio duboki povijesni trag u razvitku europske misli. I upravo zato što je prema neupitnoj tradiciji istupio kao osoba, Sokrat je optužen kako »ne poštuje atenske bogove i kvari mladež« (Bošnjak, 1978, 88).

S Platonom (428.-348.) je, međutim, manipulativnost Sokratove majeutike došla do punog izražaja. Za razliku od Sokratovih, Platonovi su dijalozi hinjeni, izmišljeni ne bi li ostavili dojam slobodnog suotkrivanja istine, iako su u cijelosti usmjereni i pod nadzorom autora. Dok je Sokratu istina svrhom svakog misaonog ili praktičkog nastojanja, Platonova je nakana ostvarenje postojane pravedne države. Pravedne, dakako, u skladu s Platonovim poimanjem apsolutne istine, u čijoj službi moraju biti svi, ali je dostupna samo izabranima. Stoga su oni predodređeni upravljati narodom, biti vladarima i učiteljima naroda, a »odgoj« je važno državno sredstvo ostvarenja »vladajuće istine« čemu svi članovi društva moraju dati svoj primjereni doprinos. I u tom rasponu od Sokrata do Platona filozofija je već oslikala razliku odgoja i manipulacije, ali joj je još nedostajalo jasnih i razgovijetnih pojmova za postaviti ne samo pitanje o toj razlici nego i presudno pitanje o odgoju: što je odgoj? Stoga se odgoj i manipulacija u to doba nekritički isprepliću ne samo u svakodnevnom odnosu roditelja i djece, učitelja i učenika, vladara i građana, nego i u filozofskim promišljanjima što su, s jedne strane, dospjela do spoznaje društvene važnosti odgoja, a s druge strane do spoznaje odgojne važnosti društva, ali ne i do spoznaje povijesnokulturne važnosti čovjekova samoodređenja. Jer, ma koliko stvaralaštvo toga doba bilo živo, njegova je povijesno-kulturna uloga i važnost još uvijek bila zastrta tradicijom pa je filozofski iskorak prema osviještenoj osobnosti, što su ga učinili sofisti i Sokrat, dugo ostao nedorečen.

I tek nakon mnogih stoljeća, s motrišta potpuno razvijene samosvijesti, Immanuel Kant (1724.-1804.) može prvi odrješito izreći zahtjev:

»Radi tako da čovječanstvo i u tvojoj osobi i u osobi svakoga drugoga svagda ujedno uzimaš kao svrhu, a nikada samo kao sredstvo.« (Kant, 2005, 50) ${ }^{3}$

${ }^{3}$ Kurziv moj. 
Time je ujedno postavljen kriterij kojim je moguće jasno razlučiti odgoj od manipulacije.

\section{Pripremno razlikovanje odgoja i manipulacije}

Tragom Kantova zahtjeva moguće je, dakle, a priori već na jezičnoj razini razlučiti odgoj od manipulacije upravo odgovorom na pitanje: označavaju li oni odnos prema čovjeku (djetetu) kao svrsi ili kao sredstvu? Čak i posve vrijednosno ravnodušno uzevši, manipulacija (lat. manipulatio: rukovanje, upravljanje) upućuje na uporabu nekoga ili nečega kao sredstva, na rukovanje ili upravljanja njime $e^{4}$ kao sredstvom radi postizanja kakvog cilja. Taj cilj, doduše, može biti dobrobit samog tog sredstva, pa bi se u tom slučaju moglo govoriti o za sredstvo dobronamjernom upravljanju što sredstvo uzima za svrhu, a to otežava razlikovanje manipulacije i odgoja po pretpostavljenoj razdjelnici »svrha-sredstvo«. Povijesno uzevši, to jest bio čest razlog njihovog nerazlikovanja.

Ipak, govoreći o upravljanju, naglasak je na sredstvu, čak kad je djelovanje usmjereno njegovoj dobrobiti, tj. kad je dobrobit sredstva cilj djelovanja.

Međutim, za razliku od izraza 'upravljanje', što je više-manje neodređen glede dobrobiti onoga čime ili kime se upravlja, riječ 'manipulacija' dobila je dodatni sloj značenja. Ona označava najčešće prikriveno ${ }^{5}$ upravljanje kime upravo radi njegovog iskorištavanja, pa i na njegovu štetu. Stoga se može reći kako je manipulacija postupak ili niz postupaka uglavnom prikrivenog upravljanja ljudima kao sredstvima radi postizanja neke njima vanjske svrhe, tj. radi pribavljanja neposredne ili posredne ${ }^{6}$ koristi manipulatoru.

\footnotetext{
${ }^{4}$ Valja zapaziti kako je to kao padež instrumental.

${ }^{5}$ Manipulacija može biti primitivna, posve otvorena, gruba, zasnovana na prisili i strahu ili ucjeni. No, takva je najmanje učinkovita, jer su je manipulirani svjesni i pružaju joj otpor koliko god mogu pa je nad njima potrebno imati stalan nadzor i raspoloživu silu koja može skršiti njihov otpor. Zato je takva manipulacija skupa, no zbog njezine jednostavnosti za njom posežu svi koji nemaju vremena ili znanja za složenije oblike manipulacije. Nekada se svaka vlast oslanjala u prvom redu na silu, ali danas su policija i vojska tek krajnja i skupa zamjena za ideološke manipulatore.

${ }^{6}$ Manipulatori često rade u korist svojih poslodavaca od kojih su za to nagrađeni, pa vlastitu korist ostvaruju posredno.
} 
U području odgoja to znači kako se manipulacijom podređuje razvoj djetetovih moći interesima i zahtjevima onih koji nad njime imaju vlast. Izraz što se rabi za prikrivanje i opravdavanje te manipulacije pred djetetom koje je počelo pružati otpor ili pred vlastitom savješću najčešće je: »To je za tvoje (djetetovo) dobro. $\ll^{7}$ Problem je, međutim, u tome što je razlikovanje manipulativnih i odgojnih postupaka promatranih izdvojeno, izvan šireg odgojnog ili manipulacijskog zbivanja, veoma otežano pa, gledani površno, često sliče jedni drugima. Primjerice, poučavanje povijesti može biti odgojni, ali i manipulativni postupak, ovisno o tome što se njime željelo postići, a što nedovoljno upućenom promatraču može ostati nepoznato, iako je u pozadini samog postupka uvijek prisutno (v. ovdje poglavlje 6).

Ako je, dakle, manipulacija odnos prema čovjeku (djetetu) što ga uzima za sredstvo ostvarenja nekog njemu vanjskog cilja i(li) postizanja koristi za drugoga - što znači kako je i sama manipulacija sredstvo jer služi nečemu izvan nje same - onda odgoj, ${ }^{8}$ nasuprot tome, mora čovjeka (dijete), kao što to izvrsno upozorava Kant, uvijek uzimati za svrhu djelovanja. A to upravo znači kako je odgoj uvijek usmjeren osobi, razvitku čovjekove osobnosti, njegove slobode kao mogućnosti samoodređenja, kojom i po kojoj tek jest i uopće može biti osoba. I po tome se odgoj (kao odgajanje i kao rezultat odgajanja) bitno razlikuje od manipulacije. Budući da sama sebi nije cilj, nego tek kao sredstvo služi postizanju nekih njoj vanjskih ciljeva, manipulacija mora biti razložna jedino na instrumentalnoj razini. Ali odgoj ne služi ničemu i zato mora imati vlastitu unutarnju svrhu i cjelovitu razložnost (Prilog 3).

\section{Zašto je odgoj sebi svrha?}

Često se o odgoju govori i piše kao o nečemu što služi ovome ili onome, ne uviđajući pritom kako ga se time svodi na manipulaciju što je

\footnotetext{
${ }^{7}$ Kasnije se na političkoj razini ta floskula neznatno mijenja i glasi: »To je za dobrobit (vas, njih) građana.«

${ }^{8}$ Valja reći kako je već davne 1934. Stjepan Matičević (1880.-1940.) dobro upozorio kako se izraz 'odgoj' u nas rabi dvoznačno, u značenju procesa i rezultata tog procesa: »Kad bi u razlici 'odgoj' i 'odgajanje' jezično bila fiksirana razlika odgojnog rezultata, dakle 'stanja odgojenosti' s jedne strane i odgoja kao procesa, odgojne djelatnosti s druge strane, bila bi to terminologijska blagodat. U našoj jezičnoj svijesti ne leži takva razlika i upotreba.« (Kujundžić i Marjanović, 1991, 171) Iako bi, dakle, bilo dobro razlikovati 'odgajanje' kao proces i ‘odgoj' kao rezultat tog procesa, u nas se u oba značenja rabi izraz 'odgoj' pa je o toj dvoznačnosti uvijek potrebno voditi računa kako bi se iz konteksta iščitalo pravo značenje.
} 
se potom opravdava ciljevima kojima treba poslužiti. Ali nije problem u tome može li se i čime opravdati manipulaciju, nego u tome mogu li se odgojni ciljevi doseći ikako drukčije doli odgojem. Jer, ako se čovjekom ne može postati mimo odgoja, onda je odgoj čovjekova sudbina,${ }^{9}$ onda upravo odgoj čovjeka čini čovjekom pa je pitanje smisla odgoja i njegove svrhe neodvojivo od pitanja smisla i svrhe čovjekova života.

Još je Jean Jacques Rousseau (1712.-1778.) napisao kako dijete pri rođenju, osim urođenih sklonosti, nema ničega od onoga što bi ga činilo čovjekom i stoga mu je, da bi to postao, potreban odgoj:

»Rađamo se slabi, trebamo snage; rađamo se lišeni svega, trebamo pomoć; rađamo se glupi, treba nam razum. Sve što nemamo rođenjem i sve što trebamo odrastajući, dano nam je odgojem. $\aleph^{10}$ (Rousseau, 1782, 4) ${ }^{11}$

A urođena sklonost što čovjeka presudno razlikuje od životinja upravo je sklonost učenju i odgojivost što je, od svih poznatih nam vrsta, ima samo čovjek. Ali ta je sklonost posljedica toga što je čovjek, za razliku od životinjskih vrsta, izgubio urođene životne programe što bi određivali njegovo ponašanje i određivali mu život mimo pitanja o smislu i svrsi života. Zato čovjek i jedino čovjek, da bi živio ljudski, mora odgovoriti na ta pitanja. ${ }^{12}$

Evolucijski mišljeno, čovjekova sposobnost i potreba za učenjem rasla je u sprezi sa slabljenjem urođenih životnih programa (instinkata i nagona ${ }^{13}$ ). Jer njihovo je slabljenje, s jedne strane, omogućavalo snažniji utjecaj učenja na ponašanje čovjeka, a s druge strane je zahtijevalo nadomještavanje učenjem oslabljenih i izgubljenih životnih programa

${ }^{9} \mathrm{O}$ tome sam opširnije pisao na drugom mjestu (Polić, 2008).

10 »Nous naissons faibles, nous avons besoin de forces; nous naissons dépourvus de tout, nous avons besoin d'assistance; nous naissons stupides, nous avons besoin de jugement. Tout ce que nous n'avons pas à notre naissance, et dont nous avons besoin étant grands, nous est donné par l'éducation.«

${ }^{11}$ Suvremeni paleontolog Richard Leakey kaže to ovako: »Rezultat toga je da gotovo cijelu prvu godinu nakon rođenja ljudske bebe žive kao embriji, rastu vrlo brzo, ali ostaju potpuno bespomoćni. Lako je vidjeti prednost odgođene zrelosti: ona omogućuje učenje kulturom.« (Leakey, 2005, 142)

12 Vidi Camus (1998).

13 Instinkti su kruti urođeni obrasci ponašanja, a nagoni su fleksibilniji obrasci što se izvršavaju zavisno o okolnostima. Tako, na primjer, ptice instinktivno grade gnijezda, pauci mreže, pčele signaliziraju drugim pčelama smjer gdje se nalazi pelud i sl. S druge strane, čovjek ne zadovoljava svoj spolni nagon instinktivno, unaprijed i čvrsto određeno, već je naučio tom nagonu udovoljiti razrađenim sustavom društveno prihvatljivih obreda $\mathrm{i}$ ponašanja. 
što su se prije nasljeđivali genski. U početku je, dakle, kultura bila tek nadomjestak genskih obrazaca ponašanja. Evolucija čovjeka, ne kao jedne među mnogim životinjskim vrstama, već upravo kao čovjeka, zbivala se zamjenjivanjem prirodnog kulturnim, sve dok kultura nije postala čovjekovim presudnim određenjem. U početku je nejaki čovjekov duh služio njegovom tijelu u borbi za opstanak, a onda je čovjekov duh sve više počeo kulturom nadograđivati njegovo nejako tijelo (Pri$\log 4$ ), sve dok kultura nije daleko nadrasla čovjekovo prirodno tijelo i dok čovjek nije postao prije svega taj duh i ta kultura, tj. kultivirani duh. U početku je čovjek bio hominid čijem su tijelu duh i kultura služili za preživjeti, ali s vremenom je čovjek postao kultivirani duh kojemu je evoluirano tijelo hominida još samo osnova vlastitog postojanja $i$ razvitka. I taj kultivirani duh sve više oblikuje, kultivira to tijelo prema vlastitim potrebama, jer je upravo kultivirani duh postao samome sebi svrha. A tijelo je to što ga, koliko omogućava, toliko i sputava, pa mu se čini kako je uza nj vezan po kazni zbog nekog pradavnog grijeha. ${ }^{14}$ Toga su bili svjesni već antički filozofi, pa Aristotel (384.-322. p.n.e.) piše:

»Dakle ovako, jedan je naš dio duša, a drugi tijelo. Prvi zapovijeda, drugi prima zapovjedi; prvi upotrebljava, drugi je podložan kao oruđe. [...]

A u duši, jedan je dio razum (koji po prirodi zapovijeda i prosuđuje o nama), a drugi dio slijedi i stvoren je primati zapovijedi. [...]

[...] nas koji smo od prvoga trena, kako se govori u tajnim svetkovinama, svi prirodno stvoreni kao da imamo platiti kaznu? Božanska je izreka starih koja kaže da duša plaća kaznu i da živimo jer smo kažnjeni zbog nekih velikih grijeha.

Doista, evo čemu nalikuje sprega tijela i duše: kao što kažu da zarobljenike u Etruriji često muče tako da ih žive zavežu licem u lice s mrtvacima, prislanjajući svaki dio jedan uz drugi, tako se čini da je duša raspeta i prilijepljena uza sve osjetilne tjelesne udove.

Ništa dakle ni božansko ni blaženo nemaju ljudi osim onoga što je jedino vrijedno mara: osim uma i razboritosti - ukoliko ih u nama ima. Od onoga što je naše, jedino se to čini besmrtnim, jedino to božanskim.« (Aristotel, 1987, $125,137)$

Biološke razlike, osim urođene sposobnosti učenja, tj. odgojivosti, između ljudi i najbližih im životinjskih srodnika neusporedivo su manje

${ }^{14}$ U mitskom mišljenju to je zapamćeno kao »istočni grijeh«. Pojevši s »drva spoznaje« (u nekim mitovima to je ujedno i »drvo života«), čovjekov je duh postao svjestan tijela u kojemu je bio zarobljen. 
nego između različitih životinjskih vrsta. Stoga je upravo odgojivost ono što ljude biološki izdvaja kao vrstu i tek odgojem dijete postaje čovjek, tj. oduhovljeno i kulturno biće. Znači li to kako je odgoj ipak samo sredstvo ostvarenja čovjeka? Ne, jer ako čovjek hoće sebe kao čovjeka, onda to znači kako sebe hoće kao odgojeno, kultivirano biće, tj. hoće upravo kao odgoj. Ali odgoj nije samo stanje, pogotovo ne neko konačno stanje, nego je i razvoj, tijek privremenih stanja, tj. odgajanje, kao što čovjek jest samo tako što biva čovjekom. ${ }^{15}$

\section{Kulturno stanje i kulturni razvoj}

Kultura u svim svojim vidovima nije nastala odjednom, niti se prenosi samo u nekom gotovom obliku. Naprotiv, čovjek ju je (a time i samoga sebe) stvarao postupno, prenosio, preoblikovao, razvijao. Povijesno uzevši, svako je kulturno stanje rezultat kulturnog razvitka, kao što je kulturni razvoj tijek kulturnih stanja, stvaralački dopunjenih i/ili preoblikovanih. Kao što kultura nastaje i mijenja se stvaralaštvom pojedinaca, tako ona opstaje i razvitku se nadaje predajom u kojoj sudjeluje čitavo društvo.

U osvit čovječanstva, u njegovom kulturnom početku, stvaralački su iskoraci bili još sasvim iznimni i nova su se kulturna postignuća širila oponašanjem, te tisućljećima održavala predajom. I odgoj se svodio na tu predaju, a sloboda se javljala tek s povremenim stvaralačkim bljeskovima. Iznimni pojedinci koji su, u inače malobrojnom čovječanstvu, svojim stvaralačkim iskoracima širili kulturni obzor, bili su proizvod slučaja, a ne odgojne namjere. Stoga i ne čudi što su od izuma ${ }^{16}$ do izuma prolazila tisućljeća. Ali ipak valja zapaziti kako je kultura moguća, a s njome i čovjek, s jedne strane stvaralačkim iskoracima, a s druge strane predajom. I dok se predajom održava i množi što već kulturno jest, stvaralaštvom biva nešto kulturno novo, drukčije, raznovrsnije, čime se kultura obogaćuje i razvija. A to znači kako su kultura i čovjek oduvijek mogući samo po stvaralaštvu i slobodi kojom je ono nošeno, pa gdje stvaralaštva više nema, gdje se postojeće zatvorilo u sebe neprijateljski prema stvaralaštvu, kultura i čovjek opstoje još samo

\footnotetext{
${ }^{15}$ Poznata je izreka: »Čovjek uči dok je živ.« No, primjerenije bi bilo reći: »Čovjek je živ dok uči.« Nakon toga je (duhovno) mrtav, samo to još ne zna.

${ }^{16}$ Izum: ono što je $i z$ uma stvaralačkim činom postalo stvarno ili na neki drugi način predmetno.
} 
kao ostaci mrtvoga duha. Ali čak i takva stagnantna kultura pripada samo ljudima i razlikuje ih od životinjskih vrsta pa se mora održavati i prenositi s naraštaja na naraštaj. Za to, međutim, nije potrebno poticati, podržavati, pa ni samo podnositi nečije stvaralaštvo. Dovoljno je neka se svi ponašaju po već poznatim i davno prihvaćenim obrascima, $t j$. skladu s narodnom izrekom što poručuje: »Pleti kotac kao otac.« Za kulturu mrtvoga duha moguće je djecu u potpunosti pripremati tradicionalno iskušanim postupcima, kojima se izvana upravlja njihovim razvitkom. Drugim riječima, za održavanje kulturnog stanja dovoljna je manipulacija, dok je za kulturni razvoj potreban odgoj što se od manipulacije razlikuje samo koliko podržava slobodu i stvaralaštvo. To ne znači kako manipulacijom nije moguće proizvesti neke društvene promjene, prije svega dirigirane društvene promjene kojima se nešto do razine povijesno već ostvarenog u jednom dijelu društva prenosi i u druge dijelove.

Za takve promjene stvaralaštvo nije potrebno, ali ni promjene ne mogu biti iznad povijesno dosegnute razine. Što ne znači opet kako se i takvim promjenama ne stvara podloga za veći broj slučajnih stvaralačkih iskoraka. Osim toga, moguće je manipulirati i društvenim razvitkom, najprije selektivnom potporom stvaralaštvu, a zatim i njegovim selektivnim suzbijanjem. No za tu je vrstu manipulacije stvaralaštvo još uvijek potrebno, iako ga se nastoji nadzirati i držati u poželjnim okvirima. Uostalom, čak ni najdemokratskija društva ne podržavaju sve oblike stvaralaštva, a spremno suzbijaju njegove oblike ocijenjene kao društveno štetne. Time se otvaraju pitanja kako odgovornog stvaralaštva, tako i uzajamno korisnog međudjelovanja pojedinca i društva, kakvo je potrebno razvijati odgojem.

Svojim suprotstavljanjem tradiciji i »kvarenjem mladeži« Sokrat je otvorio novo poglavlje odnosa pojedinca i društva što je dosljedno svjedočio i platio životom, ali je time dao zamah snagama što su nastojale izbaviti osobnost iz zatočeništva tradicije, ne poričući njezinu važnost, ali odbacujući njezinu neupitnost. Po prvi je puta Sokrat odlučnim i odgovornim činom građanskog neposluha istodobno priznao važnost tradicije (on prihvaća kaznu i ne pokušava joj izmaknuti), ali i potrebu njezine promjene (do kraja inzistira kako je u pravu), čime je pokazao kako sloboda donosi i odgovornost. Treba li dakle jedna kultura, da bi se održala živom, odgojno podržavati i poticati živost duha koji ju razvija, valja promisliti kakav je duh tome primjeren. 


\section{Kultura i osobnost}

Ono za što se Sokrat najprije založio svojom filozofijom, a onda to povijesnim činom građanske neposlušnosti i praktički zahtijevao za čovjeka, što su Rousseau i klasični njemački idealizam izdigli na razinu opće fillozofske spoznaje i vrijednosti, a francuska se revolucija politički izborila da to bude priznato i prihvaćeno kao najveće kulturno-povijesno dostignuće, bila je osobnost, a po njoj i čovjek kao osoba. Ne osoba koja bi se razvijala i izdizala na račun zajednice, već osoba nasuprot kolektivitetu koji joj onemogućava razvoj i gdje osobnost mora ostati prigušena. Ili, kako to u obranu čovjekove osobnosti Rousseau piše, nasuprot ustanova koje će:

»... [čovjeku] oduzeti njegovo apsolutno postojanje i dati mu relativno, te prenijeti $j a$ u opću cjelinu, tako da svatko posebno ne smatra sebe jedinkom, nego dijelom opće cjeline, te je primjetan samo u njoj.« ${ }^{17}$ (Rousseau, 1782, 9)

I onda Kant tome dodaje zahtjev da osoba nikada ne smije biti sredstvo čemu, već uvijek svrha svakog ljudskog djelovanja. A francuskom revolucionarnom Deklaracijom o pravima čovjeka i građanina (1789.) svakom je čovjeku priznato pravo na slobodu, na izražavanje vlastitog mišljenja i životno samoodređenje ako nije na štetu drugih ljudi. Time je određeno da se prema svakome treba pravno postupati kao s osobom. Ali zakonom zajamčena sloboda samo je mišljena, a ne zbiljska sloboda, kao što je i pravna osoba samo mišljena, a ne zbiljska osoba. Jer sloboda i osobnost nikome se ni na koji način ne mogu dati, nego ih svatko mora izboriti za sebe, a pravno se mogu zajamčiti tek određene društvene pretpostavke njihova ozbiljenja (Prilog 5). To znači kako slobodan razvoj osobnosti nije ni životarenje nasumce ni biološkom ili društvenom nuždom zadano starenje, nego umno samoodređenje. Bilo je to jasno još Aristotelu i Luciju Aneju Seneki (3./4. p.n.e. - 65. n.e.) koji su pisali ovako:

»Jednostavan je i svakome lak zaključak da onaj koji razmišlja živi više, a najviše onaj koji je razborit i koji razmatra u skladu s najtočnijim znanjem. 'Savršen život' treba priznati onima koji iskazuju razboritost i koji su razboriti. [...] Zbog toga prije priznajemo život onomu koji je budan nego spavaču, prije onomu koji misli nego onomu koji ne misli, a za ugodu od života kaže-

${ }^{17} \gg .$. lui ôter son existence absolue pour lui en donner une relative, et transporter le moi dans l'unité commune; en sorte que chaque particulier ne se croie plus un, mais partie de l'unité, et ne soit plus sensible que dans le tout.« 
mo da nastaje upotrebom duše. To je, naime, istinski život.« (Aristotel, 1987, 132-133)

"Život je dug, ako je pun. A biva pun, ako duh zadobije vlast nad sobom i nauči upravljati sobom. Što vrijedi nekome ako je nepokretno proveo osamdeset godina? On nije živio, nego životario. «18 (Seneca, 1825, 117; Ep. 93)

Rousseau pak oslanjajući se na Seneku piše ovako:

»Živjeti ne znači disati, nego djelovati, koristiti se svojim organima, svojim osjetilima, svojim sposobnostima, svim dijelovima nas samih koji nam daju osjećaj našeg postojanja. Čovjek koji je najviše živio nije onaj koji je brojio najviše godina, nego onaj koji je najviše osjetio život. Toliki je zakopan u stotoj godini, a umro je već pri rođenju. Bolje bi mu bilo da je pokopan u mladosti, a da je živio bar do tog doba. ${ }^{19}$ (Rousseau, 1782, 18)

Za razliku od mnogih, hrvatski jezik izvrsno preslikava sadržaj pojma 'osoba' na jezičnu razinu. Biti osoba znači bit svoj, pripadati i ovisiti o sebi ili, ukratko, biti slobodan (Prilog 6).

Pa ako čovjek može biti osoba tek ako pripada sebi, ovisi o sebi, bude svoj, tj. slobodan - ako živi i razvija se na neki sebi svojstven način - onda se on kao osoba nužno razlikuje od drugih i po nečemu ističe među njima. A to znači kako je svatko kao osoba poseban i osobit, tj. da se njegova osobnost razvija upravo iz njegove osobitosti, kao što se i njegova osobitost razvija s njegovom osobnošću. Jer, osobnost se kao samosvojnost, kao vlastitost, od početka može graditi samo na nečemu što pojedinog čovjeka razlikuje od drugih, što je, dakle, samo njegovo. Zato se osobnost ne gradi upravljanjem izvana, nego potporom osobitosti neka se slobodno razvija iz sebe same. Osobnost i jest slobodna osobitost.

I upravo je ta osobitost ono što osoba stvaralačkim činom, dakle činom slobode, kojim se na najbolji način potvrđuje kao osoba, ugrađuje u kulturu, čime ju obogaćuje i razvija. A to znači kako kultura živi s osobnošću onih koji su je usvojili: ne kao skup gotovih i nepromjenjivih životnih obrazaca, već kao predaju što teži preoblikovanju.

$18 »$ Longa est vita, si plena est. Impletur autem cum animus sibi bonum suum reddidit, et ad se potestatem sui transtulit. Quid illum octoginta anni iuvant per inertiam exacti? Non vixit ille, sed in vita moratus est.«

$19 »$ Vivre, ce n'est pas respirer, c'est agir, c'est faire usage de nos organes, de nos sens, de nos facultés, de toutes parties de nous-mêmes qui nous donnent le sentiment de notre existence. L'homme qui a le plus vécu n'est pas celui a compté, mais celui qui a le plus senti la vie. Tel s'est fait enterrer à cent ans, qui mourut dès sa naissance. Il eût gagné d'aller au tombeau dans sa jeunesse, s'il eût vécu du moins jusqu' à ce temps-là.« 
To nadalje znači kako sama kultura, da bi se razvijala, mora poticati i podržavati razvoj osobnosti koje će je održavati živom, jer u protivnom ona će živjeti tek toliko koliko osobnosti budu moguće ne s njom i po njoj, nego mimo nje i u sukobu s njom. Djelatnost kojom se društvo kulturno obnavlja je zato najvažnija ljudska djelatnost, a odnos prema toj djelatnosti najvažniji je odnos kulture i ljudi, tj. ljudi kao kulturnih bića, prema vlastitoj budućnosti. Ta djelatnost kojom se obnavlja kultura, kojom se obnavlja kultivirani duh, kojom se obnavlja čovjek (jer nema ljudske kulture bez čovjeka ni čovjeka bez kulture) je odgoj. ${ }^{20}$ Odgoj je ukupnost postupaka čime se, u okviru određene kulture, slobodonosno razvijaju čovjekove moći. Koliko je čovjek sam sebi svrhom, toliko je kultivirani duh sam sebi svrhom, toliko je kultura sama sebi svrhom, toliko je sebi svrhom i odgoj kojim se kultura i čovjek prožimaju i sažimaju u povijesno živuću cjelinu. ${ }^{21}$ Već odavno su kulturne tvorevine postale ne samo čuvari ljudskog duha, nego i samodograđeni produžeci čovjekovog prirodnog tijela. ${ }^{22}$ Kulturom se pojedinačni ljudski duhovi umrežavaju u zajednicu duha gdje pojedinačna dostignuća postaju opća, što znači kako svaki pojedinac upravo svojom osobitošću doprinosi duhovnoj snazi zajednice i učenjem prisvaja njezinu ukupnu duhovnu snagu.

Sasvim pojednostavljeno moglo bi se to usporediti s elektroničkim računalima. Iako hardver (tijelo) računala uvjetuje i omogućuje njegovu daljnju softversku (duhovnu) nadogradnju, ipak je računalo bez softvera samo obična stvar među stvarima, premda s bitno većom raspoloživošću (s većim »predispozicijama«). Tek sa softverom »računalo« postaje uistinu računalo, oduhovljeno oruđe u čijem je izgledu važno samo ono čime se čovjek povezuje s njime, dok je njegova prava snaga i vrijednost $\mathrm{u}$ računskim sposobnostima kojima je na usluzi čovjeku. A te se

${ }^{20}$ Zato je Platonu bilo moguće reći: »Bude li Atena imala loše postolare, njezini će građani hodati bosi. Bude li pak imala loše učitelje, Atena će propasti.« (Platon u: Bučević i Kunst, 2009, 19)

${ }^{21} \mathrm{O}$ tome Richard Leakey piše: »Ljudi postaju čovječni kroz intenzivno učenje, ne samo o opstanku u praktičnom svijetu, nego i o običajima i moralu, rodbinskim vezama i socijalnim zakonima. Drugim riječima: kultura. Za kulturu se može reći da je čovjekovo prilagođavanje.« (Leakey, 2005, 130)

${ }^{22}$ Pri tome valja osvijestiti činjenicu da se sve do 20. stoljeća čovjekov kulturni razvoj temeljio na »nasadcima« - oruđima kojima je izvana dograđivao svoje tijelo, a da sada sve važniji postaju »usadci« - kojima čovjek svoje tijelo dograđuje iznutra. Ugradnja elektroničkih integriranih krugova (čipova) u ljudsko tijelo više nije znanstvena fantastika nego stvarnost. 
sposobnosti mogu pohraniti na vanjskim medijima i prenositi s jednog odgovarajućeg hardvera na drugi. Drugim riječima, ono bitno računala, a to je duhovni obrazac po kojem djeluje, nije nužno vezano za njegovo tijelo. Motika je također oduhovljeno oruđe prilagođeno određenoj vrsti kopanja i njezin oblik upravo je to oduhovljenje, ali oblik motike neraskidivo je vezan za tvar od koje se motika sastoji. Tako su i prva računala imala ugrađene programe koji nisu bili prenosivi, nego su poput instinkta i nagona bili tvornički ugrađeni u računalo. No, tek kad je softver odvojen od hardvera - $\mathrm{i}$ kad ga je bilo moguće prenositi s jednog hardvera na drugi - počeo se naglo razvijati, jer sve što je bilo stvoreno na jednom računalu, moglo je lako i brzo postati duhom i računalnom snagom svih ostalih računala što su taj softver mogla prihvatiti.

\section{U čemu se ogleda razložnost odgoja?}

Kao osnovna djelatnost kojom se čovjek uvijek iznova povijesno određuje kao kulturno biće, odgoj mora prenositi sve čime je kultura bitno određena. A svaka je kultura pojavni oblik duha, pa makar je taj duh već mrtav i održava se pukom predajom. Ali njegov je postojeći oblik morao biti dostignut razvojem i taj je razvoj bio moguć samo dok je duh živio, dok je kao um stvarao novo, dok je novo izumom postajalo stvarnost. Stoga je u osnovi svake kulture stvaralaštvo i sloboda što ga nosi. Bitno je obilježje slobode razložnost - po kojoj se uspostavlja samoodređenje - iako je sloboda uvijek više od same razložnosti. Stoga, ako odgoj treba kulturu održavati živom, onda on mora biti razložan. To da odgoj mora biti razložan znači kako samo tako jest i može biti odgoj. U protivnom postaje nešto drugo. Razložnost odgoja ogleda se u tome što odgoj mora biti zasnovan razložno, mora se zbivati razložno i mora se razvijati razložno.

\subsection{Odgoj mora biti zasnovan razložno}

Prije svega, odgoj mora biti zasnovan razložno, s jasnom sviješću o tome što odgoj jest i što jedino može biti. Drugim riječima, odgoj može biti razložno zasnovan samo na jasnom i razgovijetnom pojmu odgoja. Jer ako tko misli kako su ribe pernati sisavci, ne može se uspješno baviti ribarstvom. Jednako se tako ne može uspješno baviti odgojem tko nije promislio pojam odgoja, tko ga uzima površno, u nekom tek približnom ili čak pogrešnom značenju i tko odgoj ne razlikuje od raznih 
oblika manipulacije. Dovoljno je zaviriti u pedagošku literaturu i osvjedočiti se u zbrku što vlada u određenju pojmova odgoja i obrazovanja. O kakvom odgoju uopće može biti riječi tamo gdje se vjeruje kako je spoznaje moguće odvojiti od vrijednosti i onda ih nuditi zasebno takozvanim »obrazovanjem i odgojem $\ll ?^{23}$ Da se odgojem često naziva i ono što se tako ne bi smjelo zvati, potvrđuje tekst u Pedagoškoj enciklopediji (1989):

»U tom smislu odgoj je proces osposobljavanja ljudi za ljudski smislen i stvaralački način reprodukcije i produkcije osnovnih uvjeta njihove egzistencije: rada, društvenih odnosa i slobodnog vremena. Ako to nije tako, onda odgoj nije odgoj, nego je aktivnost drila, tutorstva, parcijalizacije uvjetovanja, oblikovanja, indoktrinacije. Čim se aktivnost koja se naziva odgojem pretvori u upravo navedene procese, ona se ne može imenovati tim pojmom, ali se, na žalost, to često čini.«(Pedagoška enciklopedija, 1989, 138) ${ }^{24}$

Zahtjev da odgoj mora biti zasnovan razložno znači i to da pojam odgoja mora dosljedno proizlaziti iz promišljanja kulturno-povijesnog tijeka u kojemu se oblikovao, a ne da je oblikovan samovoljnim određenjima za potrebe ove ili one ideologije. I upravo je te ideološke zamke najteže izbjeći, jer pojam odgoja sadrži i njegovo vrijednosno usmjerenje, tj. u određenju toga što odgoj jest i mora biti (da bi bio odgoj) sadržano je i to što odgoj treba biti. Promišljanje kulturno-povijesnoga nastanka bilo koje pojave, naime, uvijek je određeno vrijednostima onih koji se tim promišljanjima bave i koji tim vrijednostima iščitavaju prošlost. Drugim riječima, nije samo buduće određenom prošlim, nego je i prošlo određeno budućim, tj. znanja i vrijednosti se uzajamno uvjetuju. Stoga valja osvijestiti kako smo svi mi više-manje nesvjesno pod ideološkim utjecajima, od kojih je kritičko mišljenje jedina kakva-takva brana.

\subsection{Odgoj se mora zbivati razložno}

Kao djelatnost kojom pojam zahvaća stvarnost, odgoj se mora $z b i$ vati razložno. To ne znači kako odgoj u svakom dijelu mora biti organi-

${ }^{23}$ Vidi o tome u Polić, 2006.

${ }^{24}$ Iako je osnovna misao u navodu prihvatljiva, valja ipak, s obzirom na nakanu ovoga teksta, upozoriti čitatelje na neke jezične površnosti. Piše »onda odgoj nije odgoj«, a trebalo bi »onda ono što se imenuje kao odgoj nije odgoj«. Piše »ona se ne može imenovati tim pojmom, ali se, na žalost, to često čini«. Pa ako se to često čini, znači kako se može, ali se ne bi trebalo činiti. I ne imenuje se nešto pojmom nego imenom ili nazivom, a pojam je ono što se o čemu misli. Dakle, i o pojmu treba imati jasan i razgovijetan pojam. 
ziran znanstveno i cijelim svojim tijekom mora biti unaprijed potpuno određen ostvarenjem programski zadanih sadržaja. Naprotiv, upravo bi to bilo protivno pojmu odgoja i time nerazložno. Uostalom, i programski su sadržaji nužno samo određeni vrijednosni izbor, a ne ukupnost ljudskog znanja što ga nijedan pojedinac već odavno ne može usvojiti. I taj bi izbor trebao biti na najveću dobrobit zajednice i svakog pojedinca u njoj (jer samo je tako potpuno u skladu s biti odgoja). A to znači kako bi trebao maksimalno podržavati njihovu slobodu, razvijanjem osobnosti pojedinaca i samoodređenja zajednice u cjelini. To je pak moguće samo ako je odgoj prožet slobodom. Razložnost odgoja, dakle, ni na koji način ne isključuje iz njega vrijednosti i čuvstva. Naprotiv, upravo ih razložnost odgoja pretpostavlja, toliko koliko je odgojno stvaralaštvo tek s njima moguće. Ne postoje, naime, znanstveni obrasci po kojima bi bilo moguće razvijati osobnosti u njihovoj osobitosti, nego se na osnovi znanstvenih spoznaja odgajatelj mora stvaralački dovijati primjerenim odgojnim postupcima. Pritom uvijek treba voditi računa o tome kako on pred sobom ima ne samo osobitog pojedinca nego najčešće više njih s različitim, možda i nepomirljivim sklonostima. Stoga je odgoj nadasve zahtjevna djelatnost što, $\mathrm{s}$ jedne strane, mora biti zasnovana na spoznajama raznih znanosti, kao što, s druge strane, mora biti zasnovana i na stvaralaštvu odgajatelja koji te znanstvene spoznaje umije primjereno odgojnim potrebama odgajanika preoblikovati, prilagoditi i u zadanim uvjetima primijeniti, jer samo tako može poticati i podržavati razvoj odgajanikove osobitosti i osobnosti. A to znači kako odgoj nije i ne može biti djelatnost prema unaprijed zadanom obrascu, nego je uvijek prožeta i usmjeravana pitanjima. Pitanjima što ih odgajatelj postavlja sebi o:

- kulturi što je posreduje,

- sklonosti i mogućnosti onih koje u tu kulturu uvodi kao njihov duhovni zavičaj,

- načinu kako to čini,

- sebi samome kao sudioniku duhovne predaje.

Uostalom, razložno mišljenje počinje pitanjem i razvija se razgovorom s drugima ili barem sa samim sobom. A pitanja koja mu odgajanici postavljaju, odgajatelju su smjerokaz odgojnog djelovanja i zato su dragocjena. 


\subsection{Odgoj mora razvijati razložnost}

Sva razložnost odgoja uzaludna je i jalova ako ne potiče i ne razvija razložnost onih koje se uvodi odgojem u kulturu ne da budu čuvari i prenositelji mrtvog duha, nego da kulturni duh održavaju živim, da kulturu čuvaju ali i razvijaju, da uvećavaju čovjekove mogućnosti i slobodu. Stoga odgoj mora poticati i razvijati razložnost odgajanika. Ali razložnost nije, kao što se često vjeruje, »zdrav razum«. Nešto što nam je urođeno ili dolazi samo po sebi. Kao i za sve drugo, urođena može biti tek određena sklonost razložnom mišljenju što je treba kultivirati obrazovanjem. Odavno je u filozofiji poznato kako je »zdrav razum« najčešće samo gomila predrasuda. No ni razložnost nije neko apsolutno valjano mišljenje, iako se prečesto vjeruje kako jest (Prilog 3). To što se uči iz udžbenika logike samo je kanonizirano mišljenje što može i treba također biti propitivano. Razložno je mišljenje dosljedno, konzistentno i koherentno, po unaprijed zadanim pravilima izvedeno iz osnovnih pretpostavaka. Slično kao i jezik. Ali, kao ni jezik, ni razložno mišljenje ne mora biti samo jedno. To što u znanosti posvuda vrijede isti misaoni kanoni, posljedica je toga što je prihvaćanje tih kanona uvjet ulaska u znanstvenu zajednicu. Pa tako danas i engleski jezik sve više postaje uvjet za to. Jednoga dana moglo bi se činiti kao da znanstveno govoriti i nije moguće drukčije nego engleski. Ali kao što promišljanje jezika i (raz)govor o jeziku nije moguć bez njegova poznavanja, tako ni promišljanje razložnosti nije moguće bez poznavanja »valjanih oblika misli«. Želimo li razložnost živjeti mišljenjem, a ne svesti je na mrtve kanonizirane oblike »valjanih oblika misli«, mišljenje mora ostati otvoreno pitanjima o svemu pa i o sebi samom. Jer tek pitanjima mišljenje teži biti u sebi razložno, a ne slijediti unaprijed zadane misaone obrasce. Tek s pitanjima mišljenje postaje kritičko mišljenje što se prema svijetu ne odnosi kao prema neupitnoj gotovosti, nego ga uvijek iznova obnavlja i stvaralački dograđuje. Zato valja poticati i podržavati dječja pitanja. A to prije svega znači kako njihova pitanja ne smiju ostati bez odgovora, makar odgovor glasio: »Ne znam, ali pitanje je zanimljivo i odgovor možemo pokušati naći zajedno.«

Zapravo, pitanje barem ponekad ne bi trebalo završiti od-govorom, nego bi ga valjalo razvijati i granati raz-govorom, kojim mišljenje prerasta u su-mišljenje i zadobiva duhovnu snagu zajednice. Time odgoj prerasta u su-odgoj što kao takav sažima povijesnu bit kulture. Jer, kao što je kultura oduvijek bila osnova djetetova očovječenja, tako je iz 
ljudskih osobitosti crpila građu vlastitog razvitka. Stoga je odgoj uistinu odgoj toliko koliko prerasta u suodgoj, tj. koliko se zbiva kao rastuće zajedništvo osobnosti koje se svojom različitošću kroz sumišljenje i sudjelovanje uzajamno obogaćuju.

\section{Odgoj - manipulacija - istina: primjer iz udžbenika povijesti}

Na primjeru usporedbe teksta iz dvaju udžbenika povijesti, pokazujemo kako je granica između odgoja i manipulacije te znanstvene istine i manipulacije tanja i nejasnija nego što se obično misli.

Godine 1996. u uporabi su bila dva udžbenika povijesti za 7. razred osnovne škole i nastavnici su ih mogli alternativno rabiti po vlastitom izboru. Iako su autori udžbenika različiti, oba je udžbenika objavio isti nakladnik i oba su dobila odobrenje nadležnog ministarstva. Ali ti se udžbenici sadržajno bitno razlikuju pa iste događaje ponekad prikazuju posve suprotno. Primjerice, borba za hrvatski književni jezik u doba hrvatskog narodnog preporoda $\mathrm{u}$ jednom je udžbeniku (nazovimo ga Udžbenik A) prikazana pod naslovom »... izazvale su početak borbe za jedinstveni hrvatski književni jezik«, a u drugom (Udžbenik B) pod naslovom »Jedinstven književni jezik«.

Udžbenik A: »... izazvale su početak borbe za jedinstveni hrvatski književni jezik巛

»Hrvatska u prvoj polovici XIX. stoljeća nije bila ujedinjena. Slično je bilo i s hrvatskim jezikom. Postoje tri osnovna narječja: kajkavski, čakavski i štokavski. Na svakome od njih se stvara posebna književnost, ali sva književna djela - bez obzira na kojem narječju napisana - pripadaju cjelini hrvatske književnosti. Nije još bilo niti jedinstvenog pravopisa, tj. nije bilo jedinstvenih pravila kako valja ispravno pisati.

U prvoj polovici XIX. stoljeća mlada građanska inteligencija počinje djelovati na stvaranju jedinstvenog književnog jezika za sve Hrvate. Suprotno od plemstva koje je pomalo ustupalo pred Mađarima i njihovim nastojanjima da nametnu svoj jezik u Hrvatskoj, pripadnici građanske inteligencije odlučno stupaju u obranu hrvatskog jezika, državnosti i naroda.

Među njima se posebice isticao Ljudevit Gaj. On je 1830. godine u Budimu tiskao knjižicu Kratka osnova horvatsko-slavenskoga pravopisanja. U njoj je predložio kako preurediti hrvatski pravopis. Smatrao je da bi bilo najbolje ukoliko svi Hrvati prihvate štokavsko narječje kao zajedničko. Istaknuo je i potrebu snažnijega književnog povezivanja Hrvata s ostalim južnim Slavenima.« 


\section{Udžbenik B: »Jedinstven književni jezik»}

»Svaka hrvatska pokrajina imala je svoje narječje i književnost na tome narječju. Proučite crtež 20. i odgovorite: Početkom XIX. st. Hrvatska nije bila politički i jezično ujedinjena. Znaš li zašto? Koja su to narječja? Koje hrvatske zemlje obuhvaćaju pojedina narječja? Provjerite to na zemljovidu 7.

U svih se Hrvata sve više budila nacionalna svijest, a to je spoznaja o pripadnosti jednom narodu, ljubav prema domovini, svom narodu i vlastitom jeziku. Pri buđenju nacionalne svijesti važnu je ulogu imala borba za jedinstveni književni jezik za sve Hrvate. U tom duhu su djelovali hrvatski preporoditelji koji su potekli iz redova hrvatskog plemstva i inteligencije. Pokret je svesrdno pomagalo hrvatsko plemstvo, katoličko svećenstvo i građanstvo.

Jedan dio hrvatske mladeži se školuje u Beču i Grazu (Grac), pa i u Pešti gdje dolazi u dodir s mladeži ostalih slavenskih zemalja koje su bile u sastavu Habsburške Monarhije. U njima zrije misao o tome kako je potrebno poučavati vlastiti narod da cijeni svoj jezik i svoju prošlost.«

Prateći nastavne sate više nastavnika koji obrađuju nastavnu jedinicu s tom tematikom i uz podršku istog udžbeničkog teksta, promatrač možda ne bi mogao primijetiti bitnu razliku niti bi mogao zaključiti jesu li postupci nastavnika odgojni ili manipulativni. Ništa u njihovom ponašanju, naime, ne mora biti takvo da bi mu otkrilo njihove namjere, iako ih oni nedvojbeno imaju. Stoga je, da bi se doprlo do tih namjera, potrebno raščlaniti ne samo jedan nastavni sat nego i ono što mu je prethodilo ili slijedilo.

Usporede li se navedeni udžbenički tekstovi (Prilog 7) što se rabe u nastavi, lako je zapaziti kako su subjekti opisanog povijesnog zbivanja i njihove uloge u tom zbivanju prikazani posve oprečno. To znači kako barem jedan od ta dva teksta (a možda i oba) spomenute događaje prikazuje ideološki iskrivljeno, čime učenike obmanjuje ne samo u spoznajnom, nego i u vrijednosnom smislu.

Nastavnik koji je koristio znanstveno netočan i ideološki pristran tekst (Udžbenik B), a nije opazio njegovu znanstvenu neistinitost, nedovoljno je stručan i već samim time ne može djelovati odgojno, uza sve svoje dobre namjere. Iako nesvjesno, on djeluje kao ideološki prijenos, tj. i sam je tek sredstvo manipulacije. Nastavnik pak koji je zapazio ideološku usmjerenost teksta, ali ju je iz bilo kojeg razloga odlučio zanemariti, postao je time svjesnim sudionikom manipulacije. Ako je nastavnik $\mathrm{k}$ tome sam odabrao udžbenik što će koristiti u nastavi, onda je time i jače upleten u manipulaciju ideološki pristranim tekstom.

A što je s nastavnicima koji su koristili znanstveno istinit tekst (Udžbenik A)? Je li njihovo postupanje samim time bilo odgojno? Jednim dijelom jest, ali ipak samo dijelom, tj. toliko koliko su učenicima 
omogućavali usvajanje znanstveno konzistentnog i koherentnog znanja. Problem je, međutim, u tome što znanstvene istine nisu ni apsolutne ni konačne, što se povijesno pokazalo već nebrojeno puta. Drugim riječima, nasuprot ideoloških neistina, ne stoje apsolutne i konačne, nego tek znanstvene i povijesno promjenjive istine.

U svijetlu toga moglo bi se pokazati kako je odgojnije djelovao nastavnik koji je svjesno upotrijebio ideološki pristran tekst. No, da bi se to opazilo potrebno je istražiti što je uslijedilo promatranom nastavnom satu i s kojim ciljem je nastavnik rabio taj tekst. Na sljedeći nastavni sat, naime, on je mogao donijeti alternativni udžbenik povijesti što ga koriste učenici u susjednim razrednim odjelima i ponovno s učenicima proći tekst koji opisuje povijesne događaje obrađene na prethodnom satu. I bez njegove pomoći, možda tek uz mali poticaj, učenici bi opazili proturječnosti u opisu predmetnih povijesnih događaja. A time bi se otvorilo i pitanje vjerodostojnosti udžbeničkih tekstova. I ne samo tekstova, nego se dovodi u pitanje vjerodostojnost samog nastavnika koji na prethodnom satu ničim nije dao do znanja kako je korišteni tekst bilo kako upitan, pa time i svakoga tko nastupa autoritativno.

To, dakako, može i treba povremeno učiniti svaki nastavnik, neovisno o udžbeniku što ga koristi. Povremeno, jer redovito to nije potrebno ni moguće, pa čak ni poželjno činiti. Važno je, međutim, neka učenici nauče kako najmanje treba vjerovati onima koji zahtijevaju da im se vjeruje bespogovorno i kako se istina ne dobiva gotova, već za njom valja tragati. A svaki put prema istini počinje pitanjem i samo se pitajući uvijek iznova dohvaća povijesna istina.

Nisam zaboravio uz navode napisati podatke o autorima spomenutih udžbenika. Izostavio sam ih namjerno, ali u članku ima dovoljno podataka za dovoljno radoznale koji žele istražiti sami.

\section{I kada se odgojem zove...}

Da bi, dakle, neka djelatnost bila odgojem nije je dovoljno takvom zvati. Ona je to tek ako je u skladu s promišljenim i neproturječno domišljenim pojmom odgoja. Ako se pak pokaže kako odgoj nije moguć drukčije doli pitanjima i razložnim mišljenjem, kako je djelatnost odgoja primjerena pojmu tek kao poticaj i podrška kritičkom mišljenju - to je zato što čovjek istinski biva samo kao osoba, kao slobodno biće zajednice, umnim samoodređenjem, a ne kao sredstvo ostvarenja kojih god onih vanjskih ciljeva. Stoga funkcionalna izobrazba, ma koliko bila 
visoka, koja osposobljava za ovaj ili onaj posao, ali ne i za samosvojno mišljenje, nije obrazovanje nego indoktrinacija, nije odgoj nego manipulacija. Gdje nastavnički odgovori uvijek prethode učeničkim pitanjima ili, štoviše, gdje pitaju samo nastavnici ne bi li provjerili koliko i kako su učenici zapamtili zadane im odgovore na nepostavljena pitanja, a na spontana učenička pitanja ostaju nijemi, ignoriraju ih ili čak dočekuju s odbojnošću, tamo se odgojni pomaci zbivaju samo slučajno.

\section{Literatura}

Agičić, Damir (1996), Povijest: za VII. razred osnovne škole, Zagreb: Alfa.

Aristotel (1987), O duši: Nagovor na filozofiju, Zagreb: Naprijed.

Biblija - Stari i novi zavjet (1968), Zagreb: Stvarnost.

Bučević, Petar i Kunc, Ninoslav (2009), 100 slavnih izreka i pokoja šaljiva, Zagreb: Mozaik knjiga.

Bošnjak, Branko (1978), Grčka filozofija, Zagreb: Nakladni zavod Matice hrvatske.

Camus, Albert (1998), Mit o Sizifu, Zagreb: Matica hrvatska.

Dumbović, Ivan (2005), Pedagozi značajni za praksu i teoriju odgoja: enciklopedija, Lekenik: vlastita naklada.

Dumbović, Ivan, (2005-2008), rukopisna ostavština za djelo Pedagozi značajni za praksu i teoriju odgoja: enciklopedija.

Kant, Immanuel (2003), Osnivanje metafizike ćudoređa, Zagreb: Feniks.

Kujundžić, Nedjeljko i Marjanović, Ivan (1991), Personalistička pedagogija Stjepana Matičevića, Zagreb: Katehetski salezijanski centar.

Leakey, Richard (2005), Ponovno promišljanje porijekla - U potrazi za onim što nas čini ljudima, Zagreb: Naklada Breza.

Pavličević, Dragutin i Potrebica, Filip (1996), Povijest: za VII. razred osnovne škole, Zagreb: Alfa.

Pedagoška enciklopedija (1989), 2. svezak, međurepubličko izdanje, Zagreb: Školska knjiga.

Polić, Milan (2006), Činjenice i vrijednosti, Zagreb: Hrvatsko filozofsko društvo.

Polić, Milan (2008), »Kultura kao sudbina«, Filozofska istraživanja, 28(1), str. 3-11.

Rousseau, Jean-Jacques (1782), Émile ou de l'éducation, Collection complete des óuvres de J. J. Rousseau, Citoyen de Geneve, Tome septieme, Content les II premieres Livres d'Emile, ou de l'Education, A Geneve M.DCC.LXXXII.

Seneca, Lucius Annaeus (1825), Epistolae sevlectae, In gymnasiorum usum curavit Augustus Pauly, Stuttgart. 


\section{PRILOZI}

\section{Prilog 1. Razum}

Razum je spoznajna moć duha kojom on zbilju umrtvljuje u određenu gotovost - jer prije svega sebe misli kao jednu bezvoljnost - raščlanjujući je na dijelove i fiksirajući te dijelove u njihovoj izoliranosti i apstraktnosti.

Za razliku od uma koji umujući umije (može), raz-um tek naknadno raz-umije to što je umom stvoreno. Stoga, u zbilji koju razumije razum prepoznaje otuđenu umnost kao trag uma koji mu je prethodio, jer bi mu bez toga zbilja bila nerazumljiva. Kao takav razum je nositelj znanstvenog mišljenja.

\section{Prilog 2. Um}

Um je u širem smislu cjelina čovjekovih duhovnih moći ili isto što i duh. U užem smislu je skup svih čovjekovih spoznajnih moći. Um se, za razliku od razuma, prema zbilji odnosi neposredno djelatno. Zbilja za njega nije samo gotovost što je treba nepromijenjenu spoznati, već naprotiv ono predmetno koje sâm teži prožeti. Um ne otkriva postojeće zakonitosti u zbilji, nego ih on dapače postavlja. Stoga se umna spoznaja zbiva kao djelatna promjena svijeta. Djelatnost uma je stvaralaštvo. Um je dakle i zakonodavna volja.

\section{Prilog 3. Razložnost i razlog}

Razložnost: svojstvo onoga što je razložno ili onoga koji je razložan, tj. koji (što) počiva na razlogu, koji (što) je s razlogom, koji (što) je izveden misaono valjano; logičnost. Razložnost, logičnost, valjanost mišljenja u biti je zadana usvojenim temeljnim pretpostavkama, aksiomima, i pravilima izvođenja posljedaka, tj. zaključivanja što omogućavaju misaonu sustavnost pa je nešto razlogom tek i samo unutar određenog misaonog sustava.

Razlog: uvjet valjanog mišljenja, i to kako uvjet nekog suda unutar valjanog mišljenja tako i uvjet za sâmo to mišljenje što je valjano upravo po načinu misaonih uvjetovanosti; ono što je misaono nužno kako bi se nešto na misaono nužan način zbilo; određena misao, o kojoj ovisi druga misao, sud; misao koja omogućava zaključak. Dovoljan razlog za neki sud jest onaj što ga taj sud ima kao nužan posljedak. 
Razložan: koji se zasniva na razlozima; koji postupa u skladu s razlozima. Razložno mišljenje ne bi valjalo poistovjećivati s formalno-logički kanoniziranim mišljenjem što je samo jedan mogući, iako povijesno prevladavajući, oblik razložnog mišljenja, ali u mnogočemu nedostatan. Prije svega, zbog grube razlučivosti negacije, tj. zbog svoje bivalentnosti (ili-ili), što je odgovaralo primitivnom mišljenju i rodovskoj organizaciji društva, ali što je u sve većem neskladu sa životom suvremenih ljudi i s misaonim potrebama suvremenog čovjeka. Tako, na primjer, možemo ljude podijeliti u prijatelje i ne-prijatelje, pa formalno logički uzevši reći - budući da negacija negacije čini afirmaciju - kako su naši ne-neprijatelji (ne-ne-prijatelji) naši prijatelji. Ili kao što je zapisano u Bibliji: »Tko nije sa mnom, taj je protiv mene« (Lk 11,23); »Tko nije protiv nas, taj je za nas « $(\mathrm{Mk} 9,40)$. Ali to jednostavno nije istina, jer nama većina ljudi nisu ni prijatelji ni neprijatelji, nego nešto treće (većina ljudi na svijetu su nam jednostavno neznanci pa ne mogu biti ni prijatelji ni ne-prijatelji). Time što nam nisu prijatelji ne pretvaraju se u naše neprijatelje niti se time što nam nisu neprijatelji pretvaraju u naše prijatelje. Stoga neprijatelji naših neprijatelja nisu nužno naši prijatelji, a najčešće i nisu. Osim toga, formalno-logički kanonizirano mišljenje odnosi se na stanja, a ne na zbivanja, pa sukladno tome nešto »ili jest ili nije«, a to je u osnovi netočno ili samo približno točno, jer u svijetu što se neprestano mijenja - sve »biva«, što znači kako istodobno »jest i nije«. Ili jednostavno, ako se sve neprestano mijenja, a mijenja se, onda nešto »jest« tako kako jest samo toliko koliko se promjene zanemare. Kako npr. s »da« ili »ne« istinito odgovoriti na pitanje: Je li grad u kojem živimo isti onaj od jučer? Jesmo li mi iste osobe danas i jučer?

\section{Prilog 4. Duh i tijelo}

Civilizacijom Zapada stoljećima se širi »spoznaja« kako čovjek ima duh i čovjek ima tijelo (a tome se često dodaje kako čovjek ima dušu, besmrtnu čak). Posljedica toga je višestoljetna intelektualno-društvena shizofrenija gdje su se brojni ljudi, često zvani asketama i pustinjacima, pokušavali trpljenjem tijela duhovno izdići, pročistiti i približiti ljudskom savršenstvu po mjeri i »zahtjevu« božanskog. U tijelu su, po njima, skriveni mračni nagoni, tijelo je pravi čovjekov neprijatelj, a žena, kao nedvojbeno najtjelesnija provokacija uzvišenom duhu, najopasnija je prijetnja svemu duhovnom i duševnom. Zahvaljujući ovoj čudovišnoj i nesuvisloj konstrukciji (nađite takve stavove u Bibliji ako možete!), civilizacija Zapada (čitaj: Europe i SAD) još je uvijek pod utjecajem te »kulture« pa je, na primjer, europska žena počela postajati čovjekom tek sredinom 20. stoljeća i još se uvijek bori za svoja prava na jednaku čovječnost, još uvijek vladajući krugovi misle kako je bezopasnije izlagati djecu i mlade prikazima nasilja nego obavijestima o vlastitoj spolnosti i tjelesnosti! Stoga prosječni dvanaestogodišnjak zna mnogo o ratu, oružju, ubojstvima i nasilju svake vrste - o svemu što može uništiti život, a o vlastitome tijelu i njegovoj spolnoj 
ulozi posjeduje samo zbrkane, »ispod žita« prikupljene »spoznaje« iako je riječ o funkciji što, čak i ako se neodgovorno rabi, daje samo više života, nikada, poput nasilja, manje! Čini se kako je opće i prešutno društveno prihvaćanje nasilja i uništavanja života zaostali trag stoljeća razdvojenosti tijela i duha i još uvijek prisutne potrebe nadzora nad »opasnim tijelom«, s time što se to više čak ne čini u ime napretka duha jer stoljeća zatucanosti, nesnošljivosti prema drukčijima i zaglupljivanja izobrazbom umjesto razvoja odgojem svakako nisu doprinijela razvoju duha.

Rješenje te pogubne tjelesno-duhovne shizofrenije leži u priznanju jednostavne i očigledne činjenice kako čovjek nema tijelo i nema duh (dušu), već čovjek jest istodobno i tijelo $i$ duh pa i duša! Čovjek je cjelina, koja sebe doduše prepoznaje tek po duhu, ali među čijim raznim vidovima nema nadređenih i podređenih, " viših« i »nižih«, »čistih« i »nečistih«, »časnih« i »sramnih«. I upravo je stvar istinskog odgoja da duh pripremi za nepatvorenu spoznaju te cjeline. Pokušaj »odgoja« čovjeka temeljenog na razjedinjenim i suprotstavljenim vidovima te cjeline uvijek je najpodmukliji oblik manipulacije jer nema ničeg cjelovito čovječnog u odgoju »uzvišenog duha« suprotstavljenog »poniženom tijelu«. Istinski preduvjet odgoju jest poimanje čovjeka kao nerazdvojive cjeline svih njegovih osobitosti i dimenzija. Unatoč pojedinačnim povijesnim pokušajima, kultura što joj pripadamo tek treba početi ozbiljno i sustavno stvarati uvjete za slobodan razvoj i odgoj čovjeka, priznajući to pravo bez iznimke svakom djetetu, bez politikantsko-populističko-demagoških »figa u džepu« i plodova licemjerja u srcu.

\section{Prilog 5. Mogu li?}

Događa se na početku svake akademske godine da me studenti za vrijeme nastave upitaju: »Mogu li izaći na trenutak?« Moj odgovor na tako postavljeno pitanje redovito glasi: »Ne znam, pokušajte.« Tada studenti, pokazujući znakove zbunjenosti, obično ponavljaju pitanje: »Je l' mogu izaći?«, a ja opet odgovaram: »Zaista ne znam, pokušajte.« Onda oni u pravilu, vjerojatno pritisnuti potrebom, izađu i vrate se nakon kraćeg vremena, što ja komentiram: »Dakle, sad znamo kako ste mogli izaći, ali tko Vam je to dopustio?« Svi se zbunjeno zgledaju, a upitani pokušavaju objasniti kako sam im ja dopustio izići. Tada iskoristim prigodu za uputiti ih na razliku između mišljene (apstraktne) i zbiljske mogućnosti, između smjeti i moći, između prava na što i slobode za što. Netko smije izaći, ali kada to pokuša pozli mu i ne uspije u tome, dakle ne može. Netko drugi, naprotiv ne smije izaći (zabranjeno mu je, nema dopuštenje), a ipak ustane i izađe, dokazujući svojim činom kako to može. Svakodnevno ljudi ne čine mnogo toga što žele i smiju, jer ne mogu. I svakodnevno ljudi čine mnogo toga, dokazujući kako mogu, iako ne smiju. 
Ono što se nekome može dati glede slobode, tek je mišljena, apstraktna sloboda kao pravo, te vanjski uvjeti što omogućuju ostvarenje i potvrdu tog prava kao zbiljske mogućnosti. I ti vanjski uvjeti ne nastaju samim donošenjem pravne norme, nego tek stvarnom djelatnošću društva. Npr. pravo na školovanje ne znači ništa ako nisu sagrađene i opremljene škole, ako nema nastavnika i nastavnog programa. Da bi se čovjeku zajamčio makar samo negativni vid slobode, tj. sloboda od progona i određenih ograničenja, valja društveno djelovati na sprečavanju progona i uklanjanju ograničenja. Tim više je potrebno djelovati na stvaranju uvjeta za slobodu u njezinom pozitivnom vidu. Ali čak i kada postoje, ti vanjski uvjeti još nisu zbiljska sloboda. Jer, ako čovjeku i jest moguće ponuditi uvjete i dati mu poticaj za razvoj vlastitih moći, te se moći - kao subjektivni dio mogućnosti i srž slobode za što -trebaju razvijati iz sebe samih. Tek tako netko može biti autonoman, samoodređeni pojedinac, zbiljski slobodan čovjek. Ne netko tko samo čini što hoće, jer može se htjeti i po - za vlastiti duh - nekom vanjskom određenju. Već netko čije je htijenje i djelovanje rezultat umnog samoodređenja. Stoga se slobodu u njenom pozitivnom vidu, kao slobodu za što, kao samoodređenje, ne može naprosto dobiti, nego se do nje treba uvijek iznova dovijati razvitkom vlastitih moći.

Prilog 6. 'Sloboda' i 'osoba' u jezicima

\begin{tabular}{|c|c|c|c|}
\hline \multicolumn{2}{|c|}{ sloboda } & \multicolumn{2}{|r|}{ osoba, osobnost } \\
\hline \multicolumn{2}{|c|}{$\begin{array}{c}\text { Od posvojnog refleksivnog } \\
\text { pridjeva }\end{array}$} & \multicolumn{2}{|c|}{ Od refleksivne zamjenice } \\
\hline \multicolumn{2}{|c|}{ svobb (= svoj) } & \multicolumn{2}{|r|}{ sèbi, sèbe } \\
\hline svob- & slob- & seb- & sob- \\
\hline svoboda (slov.) & sloboda (hrv.) & $\begin{array}{l}\text { o-sebi } \\
\text { oseba (slov.) }\end{array}$ & osoba $(h r v .=$ o-sebi, svoj) \\
\hline \multirow[t]{2}{*}{$\begin{array}{l}\text { swoboda } \\
\text { (polj.) }\end{array}$} & \multirow[t]{2}{*}{ stoboda (polj.) } & \multirow[t]{2}{*}{$\begin{array}{l}\text { osebnost } \\
\text { (slov.) }\end{array}$} & $\begin{array}{l}\text { osobnost (hrv. = samosvojnost, } \\
\text { vlastitost) } \\
\text { sopstvenost (srp. = vlastitost, } \\
\text { svojost) }\end{array}$ \\
\hline & & & $\begin{array}{l}\text { osobitost }(h r v .)=\text { svojstvo } \\
\text { po kojem je tko poseban, po } \\
\text { kojem se tko ističe }\end{array}$ \\
\hline svobbstvo (stcs & $a v)=$ osoba & & \\
\hline
\end{tabular}




\section{Prilog 7. Usporedba sadržaja Udžbenika A i Udžbenika B}

\begin{tabular}{|c|c|c|}
\hline Sadržaj & Udžbenik A & Udžbenik B \\
\hline Naslov teksta & $\begin{array}{l}\text {... izazvale su početak borbe za jedinstveni } \\
\text { hrvatski književni jezik }\end{array}$ & Jedinstven književni jezik \\
\hline $\begin{array}{l}\text { Stanje Hrvatske u } \\
\text { 1. polovici } 19 \text {. st. }\end{array}$ & $\begin{array}{l}\text { Hrvatska u prvoj polovici XIX. stoljeća nije bila } \\
\text { ujedinjena. }\end{array}$ & $\begin{array}{l}\text { Početkom XIX. st. Hrvatska nije bila } \\
\text { politički i jezično ujedinjena. }\end{array}$ \\
\hline Stanje jezika & Slično je bilo i s hrvatskim jezikom & \\
\hline Hrvatska narječja & $\begin{array}{l}\text { Postoje tri osnovna narječja: kajkavski, čakavski } \\
\text { i štokavski. }\end{array}$ & $\begin{array}{l}\text { Svaka hrvatska pokrajina imala je } \\
\text { svoje narječje... }\end{array}$ \\
\hline $\begin{array}{l}\text { Književnost na } \\
\text { narječjima }\end{array}$ & $\begin{array}{l}\text { Na svakome od njih se stvara posebna književ- } \\
\text { nost, }\end{array}$ & ... i književnost na tome narječju. \\
\hline $\begin{array}{l}\text { Književnost narječja } \\
\text { prema hrvatskoj } \\
\text { književnosti }\end{array}$ & $\begin{array}{l}\text { ali sva književna djela - bez obzira na kojem } \\
\text { narječju napisana - pripadaju cjelini hrvatske } \\
\text { književnosti. }\end{array}$ & \\
\hline Pravopis & $\begin{array}{l}\text { Nije još bilo niti jedinstvenog pravopisa, tj. nije } \\
\text { bilo jedinstvenih pravila kako valja ispravno } \\
\text { pisati. } \\
\text { Među njima se posebice isticao Ljudevit Gaj. } \\
\text { On je } 1830 \text {. godine u Budimu tiskao knjižicu } \\
\text { Kratka osnova horvatsko-slavenskoga pravo- } \\
\text { pisanja. U njoj je predložio kako preurediti hr- } \\
\text { vatski pravopis. Smatrao je da bi bilo najbolje } \\
\text { ukoliko svi Hrvati prihvate štokavsko narječje } \\
\text { kao zajedničko. }\end{array}$ & \\
\hline Okolnosti preporoda & $\begin{array}{l}\text { U prvoj polovici XIX. stoljeća mlada građanska } \\
\text { inteligencija počinje djelovati na stvaranju je- } \\
\text { dinstvenog književnog jezika za sve Hrvate. Su- } \\
\text { protno od plemstva koje je pomalo ustupalo pred } \\
\text { Mađarima i njihovim nastojanjima da nametnu } \\
\text { svoj jezik u Hrvatskoj, pripadnici građanske in- } \\
\text { teligencije odlučno stupaju u obranu hrvatskog } \\
\text { jezika, državnosti i naroda. }\end{array}$ & $\begin{array}{l}\text { U tom duhu [borbe za hrvatski jezik] } \\
\text { su djelovali hrvatski preporoditelji } \\
\text { koji su potekli iz redova hrvatskog } \\
\text { plemstva i inteligencije. Pokret je sve- } \\
\text { srdno pomagalo hrvatsko plemstvo, } \\
\text { katoličko svećenstvo i građanstvo. }\end{array}$ \\
\hline $\begin{array}{l}\text { Buđenje nacionalne } \\
\text { svijesti }\end{array}$ & & $\begin{array}{l}\text { U svih se Hrvata sve više budila na- } \\
\text { cionalna svijest, a to je spoznaja o } \\
\text { pripadnosti jednom narodu, ljubav } \\
\text { prema domovini, svom narodu i vlasti- } \\
\text { tom jeziku. }\end{array}$ \\
\hline Borba za hrvatski jezik & & $\begin{array}{l}\text { Pri buđenju nacionalne svijesti važnu } \\
\text { je ulogu imala borba za jedinstveni } \\
\text { književni jezik za sve Hrvate. }\end{array}$ \\
\hline Veza sa Slavenima & $\begin{array}{l}\text { [Ljudevit Gaj] Istaknuo je i potrebu snažnijega } \\
\text { književnog povezivanja Hrvata s ostalim južnim } \\
\text { Slavenima. }\end{array}$ & $\begin{array}{l}\text { Jedan dio hrvatske mladeži se školu- } \\
\text { je u Beču i Grazu (Grac), pa i u Pešti } \\
\text { gdje dolazi u dodir s mladeži ostalih } \\
\text { slavenskih zemalja koje su bile u sa- } \\
\text { stavu Habsburške Monarhije. U njima } \\
\text { zrije misao o tome kako je potrebno } \\
\text { poučavati vlastiti narod da cijeni svoj } \\
\text { jezik i svoju prošlost. }\end{array}$ \\
\hline Metodička obrada & & Provjerite to na zemljovidu 7. \\
\hline Pitanja za učenike & & $\begin{array}{l}\text { Proučite i odgovorite: »Znaš li zašto } \\
\text { [Hrvatska nije bila ujedinjena]? Koja } \\
\text { su to narječja? Koje hrvatske zemlje } \\
\text { obuhvaćaju pojedina narječja? }\end{array}$ \\
\hline
\end{tabular}

